\title{
Apakah Green Sukuk Menyebabkan Pengembalian Tidak Normal?
}

\section{Studi Kasus di Indonesia}

\author{
Manajemen Keuangan \& Pasar Modal \\ Luthfi Rahmawati Nur Hasanah \\ Magister Ekonomi Syariah \\ Universitas Islam Negeri Sunan Kalijaga \\ luthfirahmawati@yahoo.com
}

\begin{abstract}
Green sukuk must be appropriate with the stock criteria enforced by the principles of Islamic Jurisprudence (Sharia). Equity through three basic selections: sources of income, business activities, and financial factors to be recognized as Islamic stocks. However, the screening criteria can not apply universally especially to financial factors. Investor use financial ratios based on the book value of total assets or market value of the company to make a selection. This results criterion not only in different portofolio composition but also requires a variety of offsets and monitoring costs. The performance of 11 green sukuk from the JII main index using environmentally sharia screening criteria is analyzed in a multiequation framework. Multi-equation framework have advantage of utilizing information from screening different criteria. These empirical findings indicate that differences in screening criteria do not significantly affect the green sukuk performance. If there is return that deviates from the risk of green sukuk. It is necessary to streamline quantitative screening criteria to avoid confusion among investing communities.
\end{abstract}

Keywords: Green Sukuk, Sustainable Development, Criteria, Performance Measurement

\section{Abstrak}

Green sukuk harus sesuai dengan kriteria pemilihan saham yang diberlakukan oleh prinsip Yurisprudensi Islam (Syariah). Ekuitas harus melewati tiga seleksi dasar: sumber pendapatan, aktivitas bisnis, dan faktor keuangan untuk diakui sebagai saham syariah. Namun, kriteria penyaringan tidak berlaku universal terutama untuk faktor keuangan. Seseorang dapat menggunakan rasio keuangan berdasarkan nilai buku total aset atau nilai pasar dari perusahaan untuk melakukan seleksi. Dengan kriteria ini tidak hanya menghasilkan sebuah komposisi portofolio yang berbeda tetapi juga memerlukan penyeimbangan yang beragam dan biaya pemantauan ulang. Kinerja 11 green sukuk dari indeks utama JII menggunakan kriteria penyaringan syariah berwawasan lingkungan dianalisis dalam dalam kerangka multi-equation. Penggunaan sebuah kerangka kerja multi-equation memiliki keuntungan tambahan memanfaatkan informasi dari penyaringan kriteria yang berbeda. Temuan empiris ini menunjukkan bahwa perbedaan kriteria penyaringan tidak secara signifikan mempengaruhi kinerja green sukuk. Jika ada return menyimpang dari risiko green sukuk. Perlu dilakukan perampingan kriteria penyaringan kuantitatif untuk menghindari kebingungan di antara masyarakat yang berinvestasi.

Kata kunci: Investasi green sukuk, pembangunan berkelanjutan, kriteria green sukuk, dan pengukuran kinerja 


\section{Pendahuluan}

Investasi adalah salah satu cara yang digunakan untuk mengembangkan harta kekayaan yang dimiliki secara produktif. Islam menganjurkan para kaum muslimin untuk mengelola hartanya secara produktif melalui berbagai transaksi muamalah yang dibenarkan secara syariah. Saat ini sudah terdapat banyak pilihan untuk berinvestasi, baik di real asset maupun financial asset. Investasi pada asset riil merupakan asset berwujud seperti membeli tanah, rumah, emas, dan lainnya. Sedangkan asset keuangan tersedia melalui pasar modal dan pasar uang. Meski banyak produk investasi yang memberikan return tinggi, akan tetapi investor yang menanamkan modal secara syariah tidak hanya mementingkan keuntungan materi semata, namun juga harus memperhatikan dan menjaga kelestarian lingkungan.

Pertemuan Tahunan IMF di Bali membahas isu lingkungan hidup dengan menjaga kelestarian alam. Salah satu yang menjadi pembahasan terkait hal ini adalah pembiayaan kegiatan penanggulangan perubahan iklim dengan menggunakan instrumen baru yang disebut Green Sukuk. Menteri Keuangan Sri Mulyani Indrawati menganggap bahwa Green Sukuk adalah instrumen pembiayaan yang sangat penting bagi kelestarian lingkungan hidup. Sri Mulyani bersama Wakil Presiden World Bank Treasury, Arunma Oteh membahas bagaimana pemerintah bersama-sama dengan pihak swasta di seluruh dunia harus bersama-sama menjaga lingkungan untuk mendukung pertumbuhan ekonomi yang berkelanjutan. Pertumbuhan ekonomi berkelanjutan dapat dilakukan dengan membiayai industri yang telah melakukan manajemen risiko lingkungan dan sosial. Maka dari itu, industri jasa keuangan harus melakukan screening di setiap proyek industri yang akan dibiayai agar ramah lingkungan.

Definisi green sukuk menurut NDRC mengacu pada semua obligasi korporasi yang diterbitkan untuk mengumpulkan dana dalam rangka mendukung reformasi penghematan energi dan pengurangan emisi, urbanisasi hijau, efisiensi penggunaan energi bersih, pengembangan energi baru, pengembangan perputaran ekonomi, penghematan air serta pengembangan dan pemanfaatan sumber daya air yang baru, pencegahan polusi dan penanganannya, eco-agroforestry, industri yang hemat energi dan ramah lingkungan, industri dengan tingkat karbon rendah, dan proyek lain yang mendukung siklus hijau dan pengembangan proyek rendah karbon.

Pasar modal memiliki dua jenis investasi green sukuk, yaitu dengan obligasi hijau dan investasi hijau. Penilaian green sukuk digunakan untuk pengembangan industri. Pasar green sukuk terus berkembang secara global. Total jumlah obligasi hijau yang diterbitkan Kementerian Keuangan pada tahun 2019 mencapai USD 2 miliar. Instrument green sukuk terbit dalam dua seri, yaitu USD 750 miliar tenor 5,5 tahun dengan imbal 3,9\% dan USD 1,25 miliar dengan tenor 10 tahun dan imbal hasil 4,45\%. Green sukuk diperkirakan akan mengisi kekurangan sumber daya pendanaan jangka panjang yang disediakan bank dengan jumlah terbatas.

Pengukuran kinerja adalah salah satu tantangan utama untuk investor yang menginginkan green sukuk di pasar modal syariah. Investor mengharuskan ekuitas sesuai dengan indeks syariah dan mendukung kelangsungan lingkungan dengan membandingkan kinerja pengembalian dana manajer dengan ekuitas syariah yang cocok dengan tujuan dana. Untuk memenuhi kebutuhan ini, terdapat penyedia indeks syariah di Indonesia: Indeks Saham 
Syariah Indonesia (ISSI), Jakarta Islamic Index (JII), dan Jakarta Islamic Index 70 (JII70 Index). Semua saham syariah yang terdapat di pasar modal syariah Indonesia masuk ke dalam Daftar Efek Syariah (DES), baik yang tercatat di BEI maupun tidak. DES berdasarkan pada kriteria seleksi saham syariah berdasarkan peraturan OJK Nomor 35/POJK.04/2017 tentang Kriteria dan Penerbitan Daftar Efek Syariah.

Roadmap Keuangan Berkelanjutan menjelaskan, salah satu hal yang harus direalisasikan adalah pengembangan Efek bersifat utang yang tujuan penerbitannya untuk menjaga atau meningkatkan kelestarian lingkungan hidup. Landasan hukum dalam pengembangan Efek bersifat utang, Otoritas Jasa Keuangan menerbitkan Peraturan OJK mengenai Penerbitan dan Persyaratan Efek Bersifat Utang Berwawasan Lingkungan (Green Bond). Dengan mempertimbangkan Efek berupa Green Bond merupakan produk baru di pasar modal Indonesia, maka dalam penyusunan Peraturan Otoritas Jasa Keuangan ini dengan mengacu kepada standar penerbitan Efek bersifat utang berwawasan lingkungan (Green Bond) yang diterbitkan The International Capital Market Association (ICMA). Selain itu, untuk mendukung pertumbuhan berkelanjutan Otoritas Jasa Keuangan (OJK) bekerjasama dengan Kementerian Lingkungan Hidup dan Kehutanan menetapkan Kebijakan pembangunan berkelanjutan di Indonesia. untuk itu, OJK mengeluarkan POJK No.60/POJK.04/2017 Penerbitan dan Persyaratan Efek Bersifat Utang Berwawasan Lingkungan (Green Bond) untuk meningkatkan ekonomi melalui pasar modal yang mendukung sumber daya alam dan keberlangsungan lingkungan. Penerbitan green bonds oleh perusahaan Indonesia di pasar modal menjadi komitmen Indonesia dalam menangani isu-isu lingkungan melalui produk keuangan ramah lingkungan. Salah satu indeks saham berwawasan lingkungan di Indonesia adalah SRI KEHATI.

Kriteria syariah terdiri dari setidaknya tiga penyaringan dasar: kegiatan usaha, sumber pendapatan, dan posisi keuangan. Dua layar pertama bersifat kualitatif dan umumnya bersifat sama untuk semua indeks. Namun, perbedaan utama terletak pada kriteria penyaringan berdasarkan posisi keuangan. Pada kriteria penyaringan keuangan, investor diperbolehkan untuk berinvestasi dalam saham perusahaan-perusahaan yang menggunakan hutang terbatas, memiliki lebih sedikit piutang, dan menahan jumlah kas yang lebih rendah dari efek berbunga dibandingkan dengan nilai buku total aset. Kriteria pemilihan saham syariah berdasarkan pemeringkatan tertinggi terhadap rata-rata kapitalisasi pasar. Memvariasikan standar penyaringan Syariah tidak hanya mengarah pada sebuah komposisi portofolio yang berbeda (Derigs dan Marzban 2008; Rahman et al. 2010) tetapi juga kinerja pengembalian yang berbeda (Derigs dan Marzban 2009; Adamsson et al. 2014).

Indonesia hanya memiliki sedikit penelitian mengenai green sukuk yang berdampak pada kinerja portofolio. Bahkan penelitian yang dipublikasikan mengenai green sukuk masih terbatas. Sehingga timbullah tuntutan kebutuhan untuk menyelidiki dampak kriteria penyaringan Saham Syariah yang memiliki kinerja pengembalian investasi berbeda pada ekuitas Islam untuk mendukung pertumbuhan berkelanjutan untuk periode sampel harian, terutama periode keuangan satu tahun terakhir ini. Untuk menjawab pertanyaan ini, data kinerja harian tingkat indeks ekuitas untuk 55 indeks (30 indeks syariah dan 25 indeks pembangunan berkelanjutan) telah dikumpulkan dan dicocokkan dari tiga penyedia indeks ekuitas utama di Indonesia: SII, JII, dan SRI KEHATI dari 11 Juni 2018 hingga 11 Juni 2019. Indeks dianalisis dari keuntungan dana investasi; hasil empiris tidak akan bias oleh biaya 
transaksi atau karakteristik khusus yang diberikan dana investasi dibandingkan dengan yang lain (Ashraf 2014). Kriteria yang lebih luas ini membantu untuk mengurangi bias seleksi dalam interpretasi dan generalisasi hasil.

\section{Kerangka Pemikiran}

Bukti empiris dari penelitian ini menggunakan indeks yang sesuai dengan pertumbuhan berkelanjutan sekaligus indeks syariah dapat memproksikan dengan kuat pengembalian yang membawa maslahah. Hal ini membantu mengurangi kesalahan pelacakan saham syariah dan saham berkelanjutan. Indeks tidak hanya memberikan informasi aset yang sama terhadap saham yang beraneka ragam, tetapi juga menggunakan metodologi konstruksi indeks yang serupa. Kontribusi utama lain dari penelitian ini adalah penggunaan sebuah kerangka kerja multi-equation untuk penentuan model harga aset modal (CAPM) dibandingkan dengan kerangka kerja persamaan tunggal yang biasanya diterapkan dalam analisis tersebut. Kerangka kerja persamaan tunggal kurang efisien karena terdapat korelasi silang kontemporer pada error term yang mungkin timbul karena perbedaan praktik penyaringan indeks syariah, penyeimbangan ulang saham syariah dan durasi investasi. Kerangka kerja multi-equation berdasarkan model "Seemingly Unrelated Regression" (SUR) memperhitungkan korelasi kontemporer dan memungkinkan perbedaan dalam kinerja relatif indeks syariah dari berbagai penyedia indeks. Estimasi koefisien dan kualitas pengujian yang dilakukan untuk analisis empiris tersebut lebih unggul dalam hal kerangka kerja multiequation dibandingkan dengan kerangka kerja persamaan tunggal.

Temuan empiris menunjukkan bahwa green sukuk menyediakan risiko yang serupa disesuaikan pengembalian selama periode sampel dari 20 Juni 2018 hingga 11 Juni 2019. Ada bukti kinerja antara green sukuk berdasarkan kriteria penyeleksian syariah yang diadopsi oleh empat penyedia indeks utama. Green sukuk menggunakan nilai buku total aset sebagai pembagi untuk penghitungan rasio keuangan yang dilakukan, secara nominal, lebih baik daripada IEI menggunakan nilai pasar ekuitas sebagai pembagi. Green sukuk berdasarkan kriteria penyaringan Syariah berwawasan lingkungan melaporkan sumber penyimpangan abnormal return dalam bentuk yang signifikan secara statistik. Green sukuk tersebut melaporkan return abnormal positif menunjukkan penurunan return lebih curam selama krisis. Sebaliknya, green sukuk mengikuti kriteria penyaringan syariah lainnya yang mengembalikan penyimpangan ke risiko relatif green sukuk dengan indeks patokan.

Temuan penelitian ini menarik bagi pembuat kebijakan, manajer dana dan masyarakat pada investasi umum. Temuan penelitian ini menyiratkan bahwa kinerja relatif investasi ekuitas syariah setidaknya harus sebaik investasi konvensional dalam jangka panjang. Tidak ada bukti kinerja umum yang berlebihan terkait dengan kriteria penyaringan Syariah tertentu.

Harus dilakukan perampingan kriteria penyaringan Syariah untuk menghindari kebingungan di antara investasi publik. Pemikir Syariah menetapkan standar untuk ekuitas penyaringan dapat dilakukan dengan standar terpadu. Kebijakan pembuat dan pengelola dana dapat memperoleh manfaat dengan mematuhi sebuah kriteria penyaringan terpadu tanpa kerugian. Ini akan menarik lebih banyak investor muslim untuk berinvestasi di pasar modal.

Susunan penelitian ini sebagai berikut. "Tinjauan Singkat — Indeks Green Sukuk di Indonesia" menyediakan bagian tentang Indeks Green Sukuk di Indonesia, literatur yang relevan dibahas dalam bagian "Kajian Literatur", metodologi estimasi empiris disajikan di 
bagian Metodologi Evaluasi Indeks Green Sukuk di Indonesia', diikuti oleh sumber data dan statistik deskriptif di "Bagian Sumber Data dan Statistik Deskriptif" dan estimasi empiris dibahas di bagian "Hasil Empiris". Bagian terakhir adalah "Ringkasan dan Kesimpulan" yang menyimpulkan penelitian ini dengan ringkasan singkat dari temuan-temuan utama dari penelitian ini.

\section{Tinjauan Singkat — Indeks Green Sukuk di Indonesia}

Seorang investor di pasar modal syariah berinvestasi di perusahaan yang mematuhi prinsip Syariah atau dalam penawaran umum portofolio yang terdiri dari penawaran saham syariah. Salah satu tantangan utama untuk investor di pasar modal syariah adalah ukuran kinerja manajer yang juga harus memperhatikan maslahah bagi keberlangsungan lingkungan. Sebuah patokan yang terdiri dari semua saham mungkin tidak sessuai untuk menilai kinerja seorang manajer di perusahaan yang menerapkan prinsip syariah. Untuk mengatasi kekurangan ini, yang pertama Indeks saham syariah diluncurkan pada tanggal 3 Juli 2000 oleh JII diikuti oleh ISSI pada tanggal 12 Mei 2011 (IDX).

Penentuan kepatuhan Syariah terletak pada penilaian dewan Syariah yang terdiri dari ulama Indonesia. Setiap dewan menetapkan aturan berbeda untuk menyaring saham yang sesuai dengan syariah. Salah satu alasan utama keberadaan berbagai standar penyaringan Syariah adalah tidak ada pedoman yurisprudensi syariah pada sumber utama Islam yaitu, Quran, Hadis dan Ijma. Dewan syariah memperoleh prinsip-prinsip penyaringan Syari'ah dengan menggunakan analogi (Qiyas) dimana pemikir ekonomi syariah menggunakan keputusan masa lalu yang bersifat serupa untuk mendapatkan keputusan baru. Sejak saham syariah beroperasi dalam sistem pasar modal yang ada dan diperlukan untuk menyesuaikan norma konvensional, perlu penjelasan lain sebagai standar Syariah.

Terdapat kriteria penyaringan yang sangat konservatif, di mana sukuk harus mematuhi prinsip-prinsip Syariah yang lebih ketat atau mungkin lebih longgar, di mana investasi diizinkan di perusahaan yang memiliki kegiatan yang tidak sesuai dengan prinsip syariah namun masih di bawah ambang batas tertentu. Kriteria penyaringan yang berbeda dapat menyebabkan kebingungan di antara komunitas investasi. Masalah ini menimbulkan pertanyaan penting, apakah keberadaan kriteria penyaringan yang berbeda menyebabkan kinerja pengembalian yang berbeda dan dengan demikian dapat mendorong pengelola dana untuk memilih sebuah indeks patokan yang mengikuti kriteria penyaringan Shari'ah sedikit santai? Kriteria penyaringan umum untuk memasukkan keamanan dalam indeks syariah tergantung pada dua tingkat penyaringan: penyaringan kualitatif dan kuantitatif. Penyaringan kualitatif memilih saham yang bebas dari semua kegiatan perusahaan yang sangat dilarang (haram) dalam Islam. Yakni perusahaan yang bisnis utamanya memiliki transaksi keuangan yang melibatkan bunga (riba), aktivitas perjudian (maisir), minuman keras (khamr) seperti alkohol atau obat-obatan serupa yang dapat menghilangkan kesadaran seseorang, babi dan atau pengambilan risiko berlebihan (gharar) sebagai investasi spekulatif. Penyaringan kuantitatif digunakan untuk memajukan perusahaan dengan kegiatan utama halal di bawah Syariah tetapi memiliki porsi pendapatan dari kegiatan yang tidak diizinkan seperti meminjam atau meminjamkan uang dengan bunga (riba) dan/atau memiliki sebuah proporsi utama aset dalam bentuk cair. Penyaringan ini didasarkan pada rasio masing-masing prinsip yang cukup kontroversial di dalamnya komunitas Muslim. 
Tabel 1

Kriteria penyaringan indeks DES dan SRI KEHATI

\begin{tabular}{|c|c|c|}
\hline Kriteria & Daftar Efek Syariah & SRI KEHATI \\
\hline \multirow{11}{*}{$\begin{array}{l}\text { Aktivitas } \\
\text { Bisnis }\end{array}$} & $\begin{array}{l}\text { 1.tidak melakukan kegiatan dan jenis usaha } \\
\text { yang bertentangan dengan Prinsip Syariah di } \\
\text { Pasar Modal yang meliputi: }\end{array}$ & a. energi terbarukan; \\
\hline & $\begin{array}{l}\text { a) perjudian dan permainan yang tergolong } \\
\text { judi; }\end{array}$ & b. efisiensi energi; \\
\hline & b) jasa keuangan ribawi; & c. pencegahan dan pengendalian polusi; \\
\hline & $\begin{array}{l}\text { c) jual beli risiko yang mengandung unsur } \\
\text { ketidakpastian (gharar) dan/atau judi } \\
\text { (maisir); }\end{array}$ & $\begin{array}{l}\text { d. pengelolaan sumber daya alam hayati } \\
\text { dan penggunaan lahan yang } \\
\text { berkelanjutan; }\end{array}$ \\
\hline & $\begin{array}{l}\text { d) memproduksi, mendistribusikan, } \\
\text { memperdagangkan, dan/atau menyediakan: }\end{array}$ & $\begin{array}{l}\text { e.konservasi keanekaragaman hayati } \\
\text { daratdan air; }\end{array}$ \\
\hline & $\begin{array}{l}\text { 1) barang atau jasa haram zatnya (haram } \\
\text { li-dzatihi); }\end{array}$ & f. transportasi ramah lingkungan; \\
\hline & $\begin{array}{l}\text { 2)barang atau jasa haram bukan karena } \\
\text { zatnya (haram li-ghairihi) yang } \\
\text { ditetapkan oleh Dewan Syariah Nasional } \\
\text {-Majelis Ulama Indonesia; }\end{array}$ & $\begin{array}{l}\text { g. pengelolaan air dan air limbah yang } \\
\text { berkelanjutan; }\end{array}$ \\
\hline & $\begin{array}{l}\text { 3)barang atau jasa yang merusak moral } \\
\text { dan bersifat mudarat; dan/atau }\end{array}$ & h. adaptasi perubahan iklim; \\
\hline & $\begin{array}{l}\text { 4) barang atau jasa lainnya yang } \\
\text { bertentangan dengan prinsip syariah } \\
\text { berdasarkan ketetapan dari Dewan } \\
\text { Syariah Nasional -Majelis Ulama } \\
\text { Indonesia; dan }\end{array}$ & $\begin{array}{l}\text { i. produk yang dapat mengurangi } \\
\text { penggunaan sumber daya dan } \\
\text { menghasilkan lebih sedikit polusi (eco- } \\
\text { efficient); }\end{array}$ \\
\hline & $\begin{array}{l}\text { e) melakukan kegiatan lain yang } \\
\text { bertentangan dengan prinsip syariah } \\
\text { berdasarkan ketetapan dari Dewan Syariah } \\
\text { Nasional -Majelis Ulama Indonesia; }\end{array}$ & $\begin{array}{l}\text { j. bangunan berwawasan lingkungan } \\
\text { yang memenuhi standar atau sertifikasi } \\
\text { yang diakui secara nasional, } \\
\text { regional,atau internasional; }\end{array}$ \\
\hline & $\begin{array}{l}\text { 2.tidak melakukan transaksi yang bertentangan } \\
\text { dengan Prinsip Syariah di Pasar Modal; }\end{array}$ & $\begin{array}{l}\text { k. kegiatan usaha dan/atau kegiatan lain } \\
\text { yang berwawasan lingkungan lainnya }\end{array}$ \\
\hline \multirow{4}{*}{$\begin{array}{l}\text { Posisi } \\
\text { keuangan }\end{array}$} & $\begin{array}{l}\text { a) total utang yang berbasis bunga } \\
\text { dibandingkan dengan total asset tidak lebih } \\
\text { dari } 45 \% \text { (empat puluh lima persen); dan }\end{array}$ & $\begin{array}{l}\text { Market Capitalization of } \\
\text { Above Rp } 1 \text { Trillion }\end{array}$ \\
\hline & \multirow{3}{*}{$\begin{array}{l}\text { b) total pendapatan bunga dan pendapatan } \\
\text { tidak halal lainnya dibandingkan dengan total } \\
\text { pendapatan usaha dan pendapatan lain-lain } \\
\text { tidak lebih dari } 10 \% \text { (sepuluh persen) }\end{array}$} & $\begin{array}{l}\text { Assets above Rp } 1 \text { Trillion. } \\
\text {. }\end{array}$ \\
\hline & & 10 percent Free Float Ratio \\
\hline & & $\begin{array}{l}\text { Positive Price Earning Ratio } \\
\text { (PER) during the last six months }\end{array}$ \\
\hline
\end{tabular}

Tabel 1 menyediakan kriteria penyaringan yang digunakan oleh penyedia indeks DES dan SRI KEHATI. Dari Tabel 1 dapat diketahui bahwa penyedia indeks menggunakan kriteria yang berbeda. Kriteria penyaringan kualitatif menunjukkan perbedaan, indeks DES yang mengecualikan bisnis yang bertentangan dengan prisip syariah sedangkan indeks SRI KEHATI mengharuskan kegiatan perusahaan yang mendukung kelestarian lingkungan. DES merupakan rujukan utama yang digunakan sebagai indeks syariah, juga digunakan sebagai rujukan oleh indeks JII. Terdapat perbedaan metodologis dalam kegiatan usaha yang 
digunakan untuk memenuhi persyaratan. Sedangkan, untuk indeks lingkungan tidak menerapkan persyaratan khusus pada posisi keuangan perusahaan. Penyaringan yang paling fundamental adalah perusahaan Corporate Management, Environment, Community Involvement, Business Manners, Human Resources, Human Rights.

Untuk memahami perbedaan JII dengan indeks saham syariah lain di Indonesia seperti DES dan ISSI, berikut kriteria JII yang terdiri dari 30 saham emiten yang dibuat dengan urutan sebagai berikut:

- Saham dengan jenis usaha utama yang tidak bertentangan dengan prinsip syariah dan sudah tercatat lebih dari 3 bulan (kecuali termasuk dalam 10 kapitalisasi besar).

- Saham yang berdasarkan laporan keuangan tahunan atau tengah tahun memiliki rasio kewajiban terhadap aktiva maksimal sebesar $90 \%$.

- 60 saham dari susunan saham berdasarkan urutan rata-rata kapitalisasi pasar terbesar selama satu tahun terakhir.

- 30 saham dengan urutan berdasarkan tingkat likuidasi rata-rata nilai perdagangan reguler selama satu tahun terakhir.

Berdasarkan kriteria tersebut, maka setiap saat akan ada saham yang keluar masuk dalam JII yang perhitungannya dilakukan setiap enam bulan sekali. Penelitian ini menggunakan perhitungan indeks JII untuk periode perdagangan bulan Juni sampai dengan September 2019 juga berdasarkan indeks SRI KEHATI.
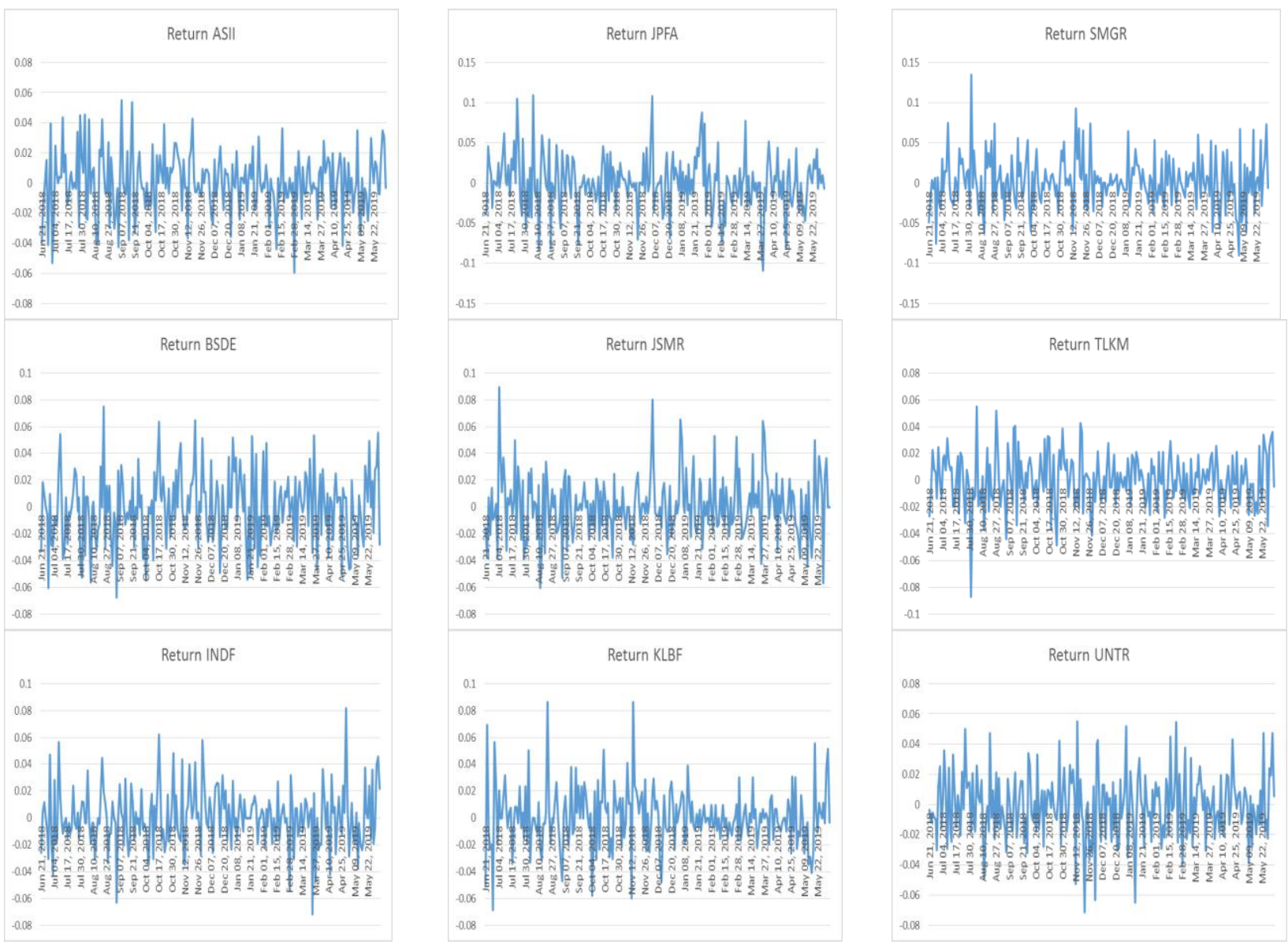


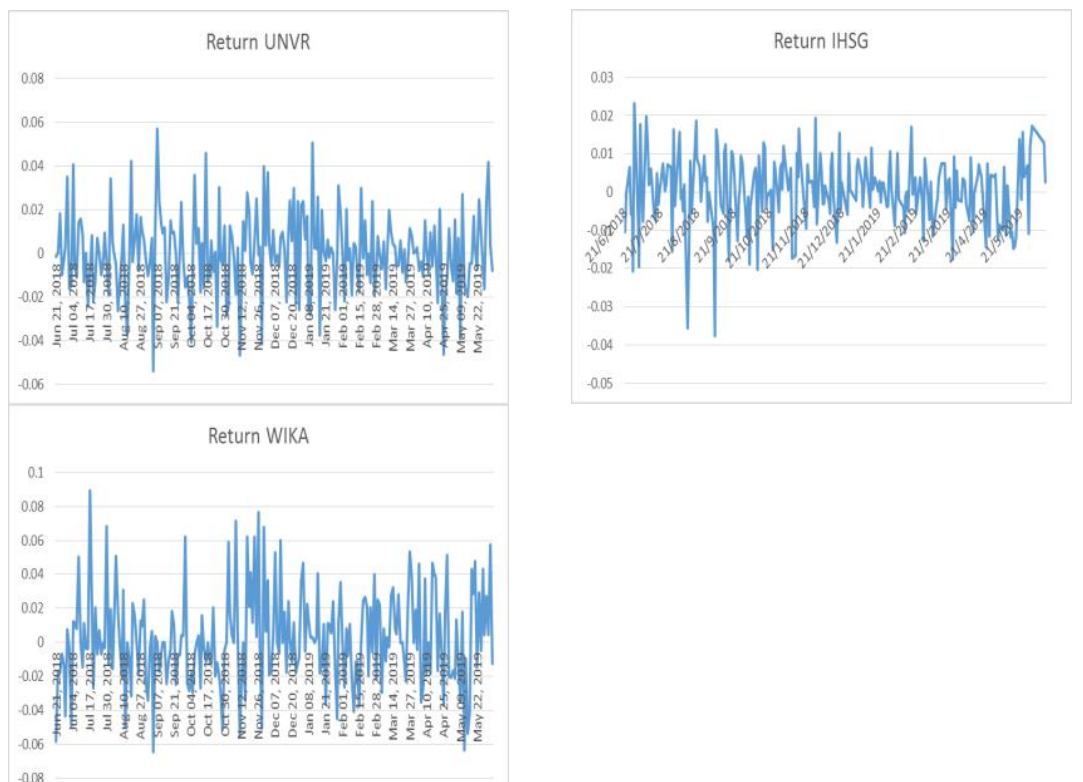

Gambar 1 menunjukkan return saham pada sebelas saham Green Sukuk yang dipilih sesuai prinsip syariah dan usaha yang berwawasan lingkungan berdasarkan kriteria penyaringan pada JII dan SRI KEHATI dari 21 Juni 2018 hingga 11 Juni 2019.

Sebelas saham yang terpilih ini sudah mematuhi semua kriteria penyaringan yang ditetapkan indeks JII maupun SRI KEHATI. Dari gambar 1 terlihat bahwa return harian pada saham Green Sukuk tersebut memiliki fluktuasi yang tinggi meskipun berbeda sektor. Namun jika dilihat dari masing-masing perusahaan, return pada saham SMGR dan UNVR memiliki fluktuasi yang lebih rendah dibandingkan dengan saham yang lain. Hal yang cukup menarik terdapat pada return IHSG pada tanggal 13 Agustus 2018 dan 5 Juni 2018 yang memiliki return yang sangat rendah dibandingkan saham lain. Dari return ini seorang investor dapat memilih saham mana yang sesuai dengan keuntungan yang diinginkan.

Dalam tingkat toleransi rasio keuangan, ambang batas ditentukan berdasarkan qiyas. Obaidullah (2005) mengkritik bahwa putusan/peristiwa sejarah digunakan sebagai penyaringan utama untuk stok berbeda dan mungkin di luar konteks. ${ }^{1}$ Ada beberapa perbedaan antara tingkat toleransi pada kriteria penyaringan JII memungkinkan ambang batas yang tertinggi untuk kapitalisasi pasar dibandingkan indeks yang lain. Sedangkan untuk kriteria penyaringan SRI KEHATI lebih menekankan pada upaya perusahaan untuk mengurangi emisi gas rumah kaca dan yang memberikan kontribusi berharga tentang pengurangan emisi yang mengandung dampak negatif dari perubahan iklim.

Perbedaan nyata ini dalam penyaringan kriteria green sukuk dan dampaknya terhadap komposisi portofolio pada akhirnya membutuhkan kinerja penyelidikan lebih lanjut. Bagian selanjutnya memberikan ulasan literatur pada kinerja investasi saham syariah berwawasan lingkungan.

\section{Kajian Literatur}

Kinerja dana ekuitas saham syariah telah mendapatkan perhatian yang cukup besar selama dekade terakhir. Namun demikian, temuan empiris ini menemukan bahwa pada kinerja komparatif Green Sukuk berdasarkan penyaringan prinsip Syariah digabung dengan prinsip wawasan lingkungan. Peneitian terdahulu mengatakan bahwa kepatuhan pemilihan

\footnotetext{
${ }^{1}$ Ashraf D (2014) dan Obaidullah (2005) mendiskusikan mengenai kriteria pemilihan keuangan.
} 
indeks syariah terjadi karena iman mereka berkinerja lebih baik terhadap agama daripada dana konvensional saat terjadi krisis ekonomi (Ashraf 2014). Kinerja ini dikaitkan dengan seleksi efek dalam ketahanan dana terhadap krisis yang menerapkan kriteria penyaringan (Ashraf 2014). Namun, ada juga penelitian yang bertentangan dengan temuan ini di mana ditemukan bahwa Islamic equity investment funds (IEIF) tertinggal di belakang indeks patokan terlepas dari kondisi pasar (Hayat dan Kraeussl 2011) menyarankan bahwa kinerja IEIF tergantung pada ukuran dan tolok ukur yang digunakan untuk evaluasi kinerja. Juga tergantung pada periode waktu yang dipilih untuk kinerja evaluasi.

Adanya biaya perdagangan, manajemen pemilihan saham dan keterampilan pemilihan waktu yang tepat, dan dampak dari seleksi syariah pada kinerja green sukuk tidak dapat diukur secara jelas. Sedangkan, literatur empiris tentang kinerja green sukuk menerapkan alpha dari model Jensen, intersep dari regresi CAPM untuk mengukur kinerja dana yang tidak normal. Fama dan French (1992) menguji CAPM secara empiris dan menemukan bahwa terdapat korelasi yang cukup tinggi antara size (ukuran saham) dan dan beta saham. Fama dan French kemudian menyarankan agar dana difokuskan pada saham kecil, beta rendah atau nilai saham cenderung menghasilkan abnormal return relatif positif signifikan terhadap tolok ukur mereka tanpa bakat khusus dari pengelola dana. Green sukuk fokus pada saham dengan leverage yang lebih rendah yang mungkin merupakan saham kecil dan/atau stok beta rendah, hasil kinerjanya masih dipertanyakan. Ini menyiratkan bahwa Green sukuk belum tentu sebuah alat yang lebih baik untuk menilai kinerja ekuitas investasi syariah baik dalam hal menilai keterampilan manajemen atau dampak dari seleksi Syariah.

Indeks JII dan SRI KEHATI menggunakan prinsip bahwa uang atau kekayaan harus dikelola dengan cara yang sesuai dengan standar dan kepercayaan moral tertentu. Hal ini bertentangan dengan praktik keuangan konvensional yang didorong untuk tujuan memaksimalkan pengembalian yang disesuaikan dengan risiko. Hal ini tidak mengabaikan upaya pengembalian investasi yang maksimal pada indeks green sukuk, tetapi perusahaan mempertimbangkan tidak hanya pengembalian ekonomi murni, tetapi juga pengembalian sosial yang diperoleh dari praktik yang sesuai dengan keyakinan dan etika. Marwan (2016) meneliti mekanisme utama dalam memastikan kepatuhan Syariah adalah dengan menerapkan berbagai aktivitas dan teknik penyaringan keuangan untuk mengkonfirmasi kesesuaian dengan standar agama dan etika Islam. Portofolio green sukuk dapat disusun untuk mendapatkan return yang sejalan dengan pembagian risiko. Schroder (2007) mengemukakan bahwa penyaringan dana yang sesuai indeks untuk perbandingan kinerja mengisolasi dampak penyaringan kinerja dari biaya perdagangan dan keterampilan manajemen.

Sebagian besar literatur empiris tentang kinerja indeks green sukuk menunjukkan bahwa JII dan SRI KEHATI setidaknya berfungsi sebagai indeks tanpa kehilangan diversifikasi (Marwan 2016; Walksha“usl dan Lobe 2012). UNDEP melihat pengembangan indeks SRI KEHATI, inovasi unik ini mendukung perkembangan di negara-negara OECD, negara berkembang. Para pemimpin Indonesia menyadari pentingnya menyelaraskan pertumbuhan ekonomi dengan tujuan sosial dan lingkungan dengan investasi berkelanjutan dan mendukung mandat OJK untuk mengembangkan sistem keuangan yang berkelanjutan. Laporan UNDP berfokus pada kemacetan di perbankan dan pasar modal yang menahan pinjaman dan investasi hijau. Intervensi publik di pasar keuangan mungkin dapat mengatasi beberapa kemacetan. Tentu, bank dan LKNB membutuhkan jalur pipa proyek yang dapat 
diinvestasikan jika mereka ingin meningkatkan bagian pinjaman dan investasi berkelanjutan.

Dalam sebagian besar studi yang dibahas di atas, penulis memiliki berfokus pada kriteria penyaringan syariah tunggal dengan menganalisis kinerja green sukuk pada data satu tahun terakhir. Rahman et al. (2010) membandingkan kriteria penyaringan untuk tingkat hutang dan tingkat likuiditas antara Indeks Islam Bursa Efek Kuala Lumpur (KLSESI) dan Dow Indeks Jones Islamic Market (DJIM). Temuan mereka menunjukkan bahwa KLSESI tidak menggunakan kedua kriteria sebagai ukuran selama proses penyaringan dan jika kedua kriteria diterapkan secara bersamaan, hanya 198 dari 565 ekuitas yang sesuai dengan saham terdaftar di KLSESI akan melewati kriteria penyaringan Syariah. Dampak pada kinerja pengembalian Investasi ekuitas syariah, Derigs dan Marzban (2009) membandingkan kinerja pengembalian yang sesuai Syariah portofolio yang diambil dari S\&P 500 berdasarkan enam berbeda standar dan menemukan bahwa standar penyaringan Syari'ah menerapkan kapitalisasi pasar untuk penyaringan keuangan berkinerja lebih baik daripada yang menerapkan nilai buku total aktiva. Namun, bukti empiris tentang penyimpangan kinerja berdasarkan berbagai kriteria penyaringan Syariah tidak bisa untuk wilayah geografis yang lebih luas dan waktu yang lebih lama periode terutama periode krisis keuangan global barubaru ini. Studi ini berupaya mengisi kesenjangan ini dengan menyediakan bukti empiris pada kinerja pengembalian penyimpangan JII mengikuti berbagai kriteria penyaringan Syariah oleh menggunakan data deret waktu yang lebih lama dengan metodologi yang kuat. Bagian selanjutnya menyajikan metodologi estimasi empiris digunakan untuk evaluasi kinerja JII.

\section{Metodologi Evaluasi Indeks Green Sukuk di Indonesia}

Model dasar untuk mengukur kinerja relatif JII berwawasan lingkungan berada dalam konteks CAPM standar dan spesifikasinya berikut:

$R_{i j}=\alpha_{i}+\beta_{i j} R_{j t}+e_{i t}$ untuk $t=1 ; 2 ; \ldots ; T ; i=1 ; 2 ; \ldots ; I$ dan $j=1 ; 2 ; \ldots ; J$

Dalam persamaan (1), seorang investor memilih portofolio yang sesuai dengan Syariah dan lingkungan (JII\&SRI-KEHATI) pada waktu, $\mathrm{t}$ - 1 yang menghasilkan pengembalian, Rit pada waktunya $\mathrm{t}$. Di mana Rjt adalah pengembalian serupa pada waktu $=\mathrm{t}$ tolok ukur $\mathrm{j}$ dari portofolio yang mematuhi hukum Syariah untuk menarik ekuitasnya. Baik Rit maupun Rjt melebihi tingkat return bebas risiko. Istilah konstanta $\alpha i$ adalah alfa dan ukuran kinerja Jensen JII\&SRI setelah pengembalian disesuaikan ke tolok ukur $\mathrm{j}$. $\beta i j=\operatorname{cov}(\mathrm{Rit} ; \mathrm{Rjt})$ /var(Rjt) Risiko tidak dapat diubah dan dapat digunakan untuk mengukur risiko relatif JII\&SRI, i dibandingkan dengan benchmark j. JII\&SRI dengan $\beta i j>1$ menunjukkan risiko relatif lebih tinggi dari JII\&SRI, i dibandingkan dengan tolok ukur j. Sedangkan $\beta i j<1$ atau $\beta i j=1$ menunjukkan bahwa JII\&SRI memiliki risiko yang relatif lebih sedikit atau risiko yang sama dibandingkan dengan tolok ukur yang ditetapkan, masing-masing indeks.

Hipotesis nol mengatakan bahwa tidak ada perbedaan kinerja dalam return JII\&SRI. Jika tidak ada perbedaan kinerja JII\&SRI dari masing-masing acuan maka $\alpha i$ tidak boleh berbeda secara statistik dari nol dan $\beta i j$ harus sama dengan 1. Schroder (2007) menyarankan menguji koefisien secara individual dan uji koefisien bersama-sama dengan hipotesis nol $H_{01}$ : $\alpha i=0, H_{02}: \beta i j=1$ dan $H_{03}:(\alpha i=0$ dan $\beta i j=1)$ dengan menggunakan uji rentang 
berdasarkan Huberman dan Kandel (1987). Tes koefisien dilakukan untuk menilai apakah JII\&SRI dapat direplikasi oleh perusahaan sebagai acuan. Jika hipotesis nol tidak ditolak, berarti seleksi yang digunakan oleh JII\&SRI tidak mempengaruhi kinerja dan menghasilkan return risiko yang serupa dengan indeks acuan.

Imbalan Pengembalian Risiko dari Penyedia Indeks Menggunakan Model SUR

Fitur umum dari karya yang dipublikasikan tentang indeks kinerja adalah penggunaan model CAPM persamaan tunggal. Dalam pendekatan ini, salah satu persamaan digunakan untuk menilai kinerja semua indeks atau beberapa persamaan independen diperkirakan secara terpisah dengan menggunakan ordinary least squares (OLS) dan mengestimasi parameter digunakan untuk memprediksi kinerja. Namun, kinerja indeks individual dapat dikorelasikan dengan indeks lainnya yang jatuh tempo ke lingkungan ekonomi, pemilihan sekuritas dan/atau faktor yang tidak secara khusus dimasukkan dalam model dan pembagian struktur kesalahan umum dengan kovarians tidak nol, sering disebut sebagai korelasi kontemporer. Estimasi OLS dari persamaan (1) tidak akan efisien secara statistik karena mengabaikan informasi tentang korelasi persamaan dengan error terms (Hakim et al. 1985). Kesalahan dalam kasus JII\&SRI dapat timbul karena terdapat Proses penyaringan syariah heterogen diadopsi oleh penyedia indeks di mana JII\&SRI menggunakan standar penyaringan Syariah yang berbeda, waktu dan frekuensi penyeimbangan yang berbeda. Alasan lain mungkin termasuk kemungkinan semesta investasi masalah cakupan di mana penyedia indeks dapat memilih sebuah semesta investasi dan cakrawala investasi berbeda untuk evaluasi kinerja.

Zellner (1962) Model Seemingly Unrelated Regression memperhitungkan korelasi kontemporer dan memungkinkan perbedaan kinerja relatif green sukuk dari penyedia indeks yang berbeda. Estimasi parameter model SUR dari semua persamaan secara bersamaan, jadi parameter dari setiap persamaan tunggal juga mengambil informasi yang disediakan oleh persamaan lain ke dalam akun. Ini menghasilkan efisiensi estimasi parameter yang lebih besar karena informasi tambahan digunakan untuk menggambarkan sistem (Hodgson et al. 2000; Schroder 2007). Persamaan (1) dapat ditulis ulang sebagai sistem persamaan:

$R_{1 t}=\alpha_{1}+\beta_{1 j} R_{1 t}+\varepsilon_{1 t} ; R_{i t}=\alpha_{i}+\beta_{i j} R_{j t}+\varepsilon_{i t}$

untuk $t=1 ; 2 ; \ldots ; T ; i=1 ; 2 ; 3 \ldots ; I$ dan $j=1 ; 2 ; 3 \ldots ; J$

Dengan model SUR, variabel dependen (Rit) diizinkan untuk memiliki variabel penjelas (Rjt) yang berbeda.

\section{Sumber Data dan Statistik Deskriptif}

Studi ini menyelidiki kinerja risiko yang disesuaikan dengan 11 JII\&SRI mengikuti standar penyaringan Syariah yang berwawasan lingkungan, dibangun dan diterbitkan oleh indeks JII dan SRI KEHATI. Untuk menilai kinerja JII\&SRI, indeks acuan untuk setiap JII\&SRI telah dipilih yang paling mencerminkan semua investasi. Sampel terdiri dari data harian indeks setahun terakhir dari 20 Juni 20118 hingga 11 Juni 2019. Data ini dipilih untuk mendapatkan informasi terkini mengenai green sukuk. Data untuk 11 perusahaan yang dipilih dan IHSG diperoleh dari yahoo.finance. Untuk uji ketahanan, data return didapatkan dengan mengolah harga saham. Secara matematis, return bisa didapat dengan: $r=(\mathrm{Pt}-\mathrm{Pt}-1) / \mathrm{Pt}-1$

Tabel 1 memberikan informasi rinci tentang indeks dan statistik deskriptif seperti kelebihan return untuk JII\&SRI dan dengan perbandingan masing-masing acuan. Rasio 
Sharpe umumnya digunakan untuk menentukan peringkat portofolio dalam hal tradeoff risiko-pengembalian mereka. Secara matematis, itu bisa ditulis sebagai:

$$
\text { Rasio Sharpe }=\frac{R_{i}-R_{f}}{\sigma_{\bar{i}}}
$$

di mana ( $\mathrm{Ri}$ - Rf) adalah kelebihan return indeks tahunan i over rate bebas risiko dan ri adalah standar deviasi dari return indeks. Persamaan (3) menggunakan Rasio Sharpe.

Perbandingan rata-rata return dan risiko disesuaikan dengan acuan kinerja IHSG konvensional menunjukkan bahwa dalam 11 indeks, JII\&SRI berkinerja lebih baik daripada acuan konvensional atas dasar pengembalian tahunan sebagai risiko yang disesuaikan melalui rasio Sharpe. Di antara saham yang terpilih, JSMR telah menghasilkan kelebihan return $5,79 \%$ relatif terhadap indeks acuan JII\&SRI. Di antara green sukuk yang berkinerja terburuk adalah UNTR, UNVR, dan SMGR berada di urutan terakhir dengan kelebihan return $-1,15 \%$, $-1.01 \%$, dan $-0.85 \%$ pada masing-masing saham setahun terakhir.

\section{Hasil Empiris}

Hasil empiris dari CAPM dan uji hipotesis ${ }^{H_{01}}: \alpha i=0,{ }_{02}: \beta i j=1$ dan ${ }^{H_{03}}$ : $(\alpha i=0$ dan $\beta i j=1$ ) untuk green sukuk mengacu pada acuan yang dikembangkan dalam Persamaan. (2) diestimasi menggunakan Metode Newey dan West (1987) yang mengoreksi varians dan matriks kovarians dari residu untuk autokorelasi dan heteroskedastisitas. Tabel 3 melaporkan hasil estimasi regresi pada sebelas saham terpilih. Hasil ini menemukan bahwa tidak ada green sukuk yang melaporkan pengembalian abnormal bentuk alfa Jensen. Alfa Jensen sebesar $0.03 \%$ adalah positif dan sedikit signifikan untuk melakukan investasi pada green sukuk. Sementara di kasus risiko sistematis, semua green sukuk melaporkan adanya koefisien yang signifikan namun besarnya beta perbeda-beda tiap perusahaan. Hasil regresi dari setahun terakhir ini menunjukkan bahwa return green sukuk memiliki hasil yang positif terhadap saham JSMR, KLBF, SMGR, dan WIKA tetapi negatif untuk 7 saham lainnya sehingga disarankan agar memilih green sukuk dari pasar saham yang memiliki risiko sistematis yang positif. Hal ini menunjukkan bahwa terdapat 7 saham yang memenuhi kriteria green sukuk yang memiliki risiko sistematis yang bernilai negatif. Untuk itu, 7 saham ini akan menghasilkan abnormal return di pasar modal syariah dan tentunya untuk memprediksi risiko dan return akan lebih sulit karena hasil prediksi yang kurang presisi dibandingkan dengan saham yang memiliki risiko sistematis. 
Tabel 2

Hasil regresi dari persamaan tunggal

\begin{tabular}{|c|c|c|c|c|}
\hline Perusahaan & Variabel & $\operatorname{Alfa}\left(\alpha_{i}\right)$ & $\operatorname{Beta}\left(\beta_{i j} R_{j t}\right)$ & Error $\left(e_{i t}\right)$ \\
\hline \multirow[t]{4}{*}{ ASII } & $R_{A S H_{t} t}=$ & 0.000262 & $1.369326^{R_{\text {IHSG }} t}$ & \\
\hline & & $(0.269104)$ & $(12.91482)^{* * *}$ & \\
\hline & \multicolumn{4}{|c|}{ R-square $\quad=0.418244$} \\
\hline & \multicolumn{4}{|c|}{ Adjusted R-square $=0.415736$} \\
\hline \multirow[t]{4}{*}{ BSDE } & $R_{B S D E_{z} t}$ & -0.000985 & $1.529283^{R_{\text {IHSG }} t}$ & \\
\hline & & $(-0.694123)$ & $(9.909706)^{* * *}$ & \\
\hline & \multicolumn{4}{|c|}{ R-square $\quad=0.297400$} \\
\hline & \multicolumn{4}{|c|}{ Adjusted R-square $=0.294372$} \\
\hline \multirow[t]{4}{*}{ INDF } & $R_{M N D F_{n} t}$ & $-1.32 \mathrm{E}-05$ & $1.492205^{R_{I H S G_{\imath} t}}$ & \\
\hline & & $(-0.012308)$ & $(12.75249) * * *$ & \\
\hline & \multicolumn{4}{|c|}{ R-square $\quad=0.412102$} \\
\hline & \multicolumn{4}{|c|}{ Adjusted R-square $=0.409568$} \\
\hline \multirow[t]{4}{*}{ JPFA } & $R_{J P F A_{s} t}$ & 0.000147 & $1.059718^{R_{\text {IHSG, }}}$ & \\
\hline & & $(0.070613)$ & $(4.680239) * * *$ & \\
\hline & \multicolumn{4}{|c|}{ R-square $\quad=0.086271$} \\
\hline & \multicolumn{4}{|c|}{ Adjusted R-square $=0.082333$} \\
\hline \multirow[t]{4}{*}{ JSMR } & $R_{J S M R_{2} t}$ & 0.000849 & $1.376279^{R_{\text {IHSG }} \mathrm{t}}$ & \\
\hline & & $(0.680101)$ & $(10.13867)^{* * *}$ & \\
\hline & \multicolumn{4}{|c|}{ R-square $\quad=0.307034$} \\
\hline & \multicolumn{4}{|c|}{ Adjusted R-square $=0.304047$} \\
\hline \multirow[t]{4}{*}{ KLBF } & $R_{K L B F_{n} t}$ & 0.000340 & 1.377664 & \\
\hline & & $(0.290842)$ & $(10.82910) * * *$ & \\
\hline & \multicolumn{4}{|c|}{ R-square $\quad=0.335756$} \\
\hline & \multicolumn{4}{|c|}{ Adjusted R-square $=0.332893$} \\
\hline
\end{tabular}

\begin{tabular}{|c|c|c|c|c|}
\hline Perusahaan & Variabel & Alfa $\left(\alpha_{i}\right)$ & $\operatorname{Beta}\left(\beta_{i j} R_{j t}\right)$ & Error $\left(e_{i t}\right)$ \\
\hline \multirow[t]{4}{*}{ SMGR } & $R_{S M G R, t}$ & 0.001556 & $1.980278^{R_{\text {IHSG,t }}}$ & \\
\hline & & $(0.950316)$ & $(11.12128)^{* * *}$ & \\
\hline & \multicolumn{4}{|c|}{ R-square $\quad=0.347734$} \\
\hline & \multicolumn{4}{|c|}{ Adjusted R-square $=0.344922$} \\
\hline \multirow[t]{4}{*}{ TLKM } & $R_{T L K M, t}$ & 7.32E-05 & $1.327410^{R_{\text {IHSG, }}}$ & \\
\hline & & $(0.077131)$ & $(12.85463) * * *$ & \\
\hline & \multicolumn{4}{|c|}{ R-square $\quad=0.415972$} \\
\hline & \multicolumn{4}{|c|}{ Adjusted R-square $=0.413455$} \\
\hline \multirow[t]{4}{*}{ UNTR } & $R_{\text {UNTR,t }}$ & -0.000952 & $1.161849^{R_{I H S G_{2}, t}}$ & \\
\hline & & $(-0.777872)$ & $(8.725799)^{* * *}$ & \\
\hline & \multicolumn{4}{|c|}{ R-square $\quad=0.247094$} \\
\hline & \multicolumn{4}{|c|}{ Adjusted R-square $=0.243849$} \\
\hline \multirow[t]{4}{*}{ UNVR } & $R_{U N V R_{t} t}$ & -0.000134 & $1.232989^{R_{I H S G_{i} t}}$ & \\
\hline & & $(-0.146095)$ & $(12.37218) * * *$ & \\
\hline & \multicolumn{4}{|c|}{ R-square $=0.397514$} \\
\hline & \multicolumn{4}{|c|}{ Adjusted R-square $=0.394917$} \\
\hline \multirow[t]{4}{*}{ WIKA } & $R_{\text {WIKA,t }}$ & 0.001750 & $1.572474^{R_{I H S G_{, t}}}$ & \\
\hline & & $(1.136834)$ & $(9.393867)^{* * *}$ & \\
\hline & \multicolumn{4}{|c|}{ R-square $\quad=0.275554$} \\
\hline & \multicolumn{4}{|c|}{ Adjusted R-square $=0.272431$} \\
\hline
\end{tabular}

Hasil estimasi dari persamaan (1) menggunakan data harian selama satu tahun terakhir. $* * *$ Hasil statistik tidak nol, tingkat kepercayaan $1 \%$, ** tingkat kepercayaan 5\%.* tingkat kepercayaan $10 \%$ 
Tabel 3

Hasil regresi multi-equation menggunakan model estimasi Cross-section SUR

\begin{tabular}{|l|c|l|l|}
\hline \multicolumn{1}{|c|}{ Cross_id } & \multicolumn{3}{c|}{ Representation } \\
\hline RETURN_ASII & -0.0000135 & 0.0002810 & $1.3538919^{*}$ RIHSG_ASII \\
\hline RETURN_BSDE & -0.0012065 & 0.0002810 & $1.3538919^{*}$ RIHSG_BSDE \\
\hline RETURN_INDF & -0.0002475 & 0.0002810 & $1.3538919^{*}$ RIHSG_INDF \\
\hline RETURN_JPFA & -0.0002336 & 0.0002810 & $1.3538919^{*}$ RIHSG_JPFA \\
\hline RETURN_JSMR & 0.0005753 & 0.0002810 & $1.3538919^{*}$ RIHSG_JSMR \\
\hline RETURN_KLBF & 0.0000672 & 0.0002810 & $1.3538919^{*}$ RIHSG_KLBF \\
\hline RETURN_SMGR & 0.0014867 & 0.0002810 & $1.3538919^{*}$ RIHSG_SMGR \\
\hline RETURN_TLKM & -0.0002167 & 0.0002810 & $1.3538919^{*}$ RIHSG_TLKM \\
\hline RETURN_UNTR & -0.0012982 & 0.0002810 & $1.3538919^{*}$ RIHSG_UNTR \\
\hline RETURN_UNVR & -0.0004558 & 0.0002810 & $1.3538919^{*}$ RIHSG_UNVR \\
\hline RETURN_WIKA & 0.0015425 & 0.0002810 & $1.3538919^{*}$ RIHSG_WIKA \\
\hline & $(0.844403)$ & $(37.40267)^{* * * *}$ \\
\hline & \multicolumn{3}{|c|}{ R-square } \\
\hline
\end{tabular}

Hasil estimasi dari persamaan 2

Untuk lebih memahami hasil ini, uji koefisien dilakukan dengan menggunakan tes Wald sebagaimana dijelaskan dalam Schroder (2007) dan Judge et al. (1985) untuk tiga hipotesis nol seperti yang dijelaskan di atas di bawah $H_{01}-H_{03}$, dan dilaporkan dalam tiga baris terakhir di bawah masing-masing green sukuk pada Tabel 3. Uji statistik untuk alpha Jensen dengan hipotesis nol $H_{01}: \alpha_{i}=0$, tidak dapat ditolak. Uji koefisien menggunakan hipotesis nol $H_{02}: \beta_{i j}=1$ untuk risiko sistematik yang sama $\left(\beta_{i j}\right)$ ditolak selama green sukuk menunjukkan risiko / kinerja return yang berbeda. Berdasarkan uji wald dapat diketahui bahwa tidak ada hubungan antara alfa dan beta.

Hasil uji menunjukkan bahwa tidak ada green sukuk yang menolak hipotesis nol ketiga ditingkat signifikansi $10 \%$. Hal ini menunjukkan bahwa green sukuk telah menghasilkan alpha yang sangat berbeda dari nol dan beta secara signifikan berbeda secara independen dari persatuan dan juga bersama. Untuk IEI yang tersisa, dengan tidak adanya alpha Jensen signifikan dan beta signifikan secara statistic koefisien, dapat dikatakan bahwa ada lebih dari (di bawah) kinerja IEI adalah karena lebih tinggi (lebih rendah) dianggap sistematis risiko dalam bentuk koefisien $\beta_{i j}$.

Kesimpulannya, hasil di atas menunjukkan bahwa sebagian besar green sukuk menunjukkan kinerja pengembalian yang sangat berbeda dari indeks acuan yang digunakan. Namun penyimpangan ini terjadi tidak berasal dari pengembalian abnormal seperti yang ditunjukkan oleh koefisien alfa Jensen yang tidak signifikan. Koefisien $\beta_{i j}$.yang signifikan di sebagian perusahaan syariah berwawasan lingkungan menunjukkan bahwa mayoritas green sukuk hanya menyimpang dari tolok ukur mereka dalam hal risiko sistematis. Temuan ini menunjukkan bahwa seorang investor pada green sukuk dapat mengharapkan setidaknya hasil pengembalian risiko yang serupa pada patokan. 


\section{Tabel 4}

Hasil regresi multi-equation menggunakan model estimasi Cross-section SUR

\begin{tabular}{|c|c|c|c|c|}
\hline Cross_id & \multicolumn{4}{|c|}{ Representation } \\
\hline RETURN_ASII & -0.008009 & 0.011136 & $1.037388 *$ RIHSG & $27.414265 * \mathrm{CRSH}$ \\
\hline RETURN_BSDE & -0.000980 & 0.011136 & 1.037388*RIHSG & $27.414265 * \mathrm{CRSH}$ \\
\hline RETURN_INDF & -0.008316 & 0.011136 & $1.037388 *$ RIHSG & $27.414265 * \mathrm{CRSH}$ \\
\hline RETURN_JPFA & -0.005770 & 0.011136 & $1.037388 *$ RIHSG & $27.414265^{*} \mathrm{CRSH}$ \\
\hline RETURN_JSMR & 0.057767 & 0.011136 & $1.037388 *$ RIHSG & $27.414265^{*} \mathrm{CRSH}$ \\
\hline RETURN_KLBF & 0.002288 & 0.011136 & 1.037388*RIHSG & $27.414265 * \mathrm{CRSH}$ \\
\hline RETURN_SMGR & -0.008482 & 0.011136 & $1.037388 *$ RIHSG & $27.414265^{*} \mathrm{CRSH}$ \\
\hline RETURN_TLKM & -0.001761 & 0.011136 & 1.037388*RIHSG & $27.414265 * \mathrm{CRSH}$ \\
\hline RETURN_UNTR & -0.011525 & 0.011136 & $1.037388 *$ RIHSG & $27.414265 * \mathrm{CRSH}$ \\
\hline RETURN_UNVR & -0.010587 & 0.011136 & 1.037388*RIHSG & $27.414265 * \mathrm{CRSH}$ \\
\hline \multirow[t]{4}{*}{ RETURN_WIKA } & -0.004625 & 0.011136 & $1.037388 *$ RIHSG & $27.414265 * \mathrm{CRSH}$ \\
\hline & \multicolumn{2}{|c|}{$(23.75290) * * *$} & $(31.69751)^{* * *}$ & $(29.03218)^{* * *}$ \\
\hline & \multicolumn{4}{|c|}{ R-square $\quad=0.524308$} \\
\hline & \multicolumn{4}{|c|}{ Adjusted R-square $=0.522079$} \\
\hline
\end{tabular}

Hasil estimasi dari persamaan 3

Hasil estimasi, dengan menggunakan kerangka kerja multi-equation seperti yang dikembangkan dalam Persamaan. (3), dilaporkan dalam Tabel 4 untuk seluruh sampel dan dengan indeks syariah berwawasan lingkungan. Sebelum menyajikan hasil estimasi, perlu diketahui apakah model SUR sesuai untuk estimasi. Uji Breusch and Pagan (1979) untuk independensi dilakukan untuk memisahkan persamaan sistem dalam penelitian ini untuk seluruh kelompok dan untuk indeks individual dengan hipotesis nol tidak berkorelasi istilah kesalahan dengan error term. Model SUR cocok jika hipotesis nol ditolak. Hipotesis nol ditolak jika tidak ada korelasi pada tingkat signifikansi $1 \%$ untuk seluruh sampel dan untuk masing-masing penyedia, yang menunjukkan adanya korelasi persamaan silang kontemporer. Sehingga, persamaan dikembangkan untuk memperkirakan kinerja saham dengan seemingly unrelated system. Karena itu, pendekatan estimasi Zellner (1962) (SUR) sesuai tujuan ini.

Tabel 4 melaporkan hasil estimasi untuk kinerja seluruh sampel yang sudah terpilih dalam indeks JII\&SRI sebagai kelompok yang menggunakan kerangka multi-equation. Hasil ini secara kualitatif mirip dengan hasil model persamaan tunggal seperti yang dilaporkan pada Tabel 3 untuk keseluruhan sampel. koefisien $\beta_{i j}$ untuk 11 green sukuk lebih rendah volatilitasnya dari model persamaan tunggal. Dalam kasus kerangka kerja multi-equation, ada bukti alpha positif dan sedikit signifikan. Penerapan hasil model SUR dalam kesenjangan yang jelas dalam kasus CRSHt dari green sukuk yang menggunakan nilai buku total aset sebagai pembagi melaporkan dengan koefisien positif dan signifikan untuk JII\&SRI.

Dalam uji koefisien, hipotesis nol pada abnormal return, risiko sistematis yang sama secara individual dan bersama-sama ditolak pada tingkat signifikansi $10 \%$. Hasil ini menunjukkan bahwa green sukuk, sebagai sebuah kelompok, tidak hanya menyediakan tingkat risiko sistematis yang berbeda secara signifikan dibandingkan dengan indeks konvensional tetapi juga menawarkan beberapa manfaat pilihan saham. Koefisien pengembalian abnormal signifikan menjamin penyelidikan lebih lanjut untuk melihat kembali sumber tidak normal oleh penyedia indeks individual.

Hasil empiris berdasarkan model SUR dikembangkan dari Persamaan. (3) untuk green 
sukuk setelah penyaringan kriteria Syari'ah berwawasan. Perbedaan utama antara kinerja keseluruhan adalah alpha Jensen yang signifikan. Koefisien CRSHt sedikit signifikan untuk green sukuk terpilih tetapi dengan tanda yang berlawanan. Hasil alpha yang signifikan menunjukkan biaya yang terkait dengan abnormal return. Uji koefisien untuk abnormal return ditolak sebesar $10 \%$ maka risiko sistematis yang sama dan rentang ditolak pada level signifikansi $1 \%$. Secara keseluruhan, hasil uji menunjukkan bahwa saham menyimpang secara signifikan dari indeks acuan dan menawarkan beberapa abnormal return di pasar.

Hasil empiris dari model SUR mengkonfirmasi terdapat berbagai versi kriteria penyaringan Syariah yang diadopsi oleh penyedia indeks menghasilkan kinerja deviasi. Hanya saham yang mengikuti kriteria penyaringan sukuk syariah berwawasan lingkungan dapat menawarkan beberapa manfaat pemilihan saham. Namun abnormal return dikaitkan dengan saham kecil dan menengah mencerminkan kerugian yang relatif lebih tinggi selama krisis keuangan global. Saham syariah menggunakan kriteria penyaringan pemilihan stok manfaat lainnya untuk semua ekuitas yang serupa. Manfaat yang jelas dari investasi di risiko sistematis green sukuk akan lebih rendah dengan hasil pengembalian risiko yang sama seperti indeks konvensional. Hasil ini sejalan dengan temuan Ashraf (2014) bahwa kinerja indeks syariah tidak berbeda secara signifikan dari indeks konvensional.

\section{Ringkasan dan Kesimpulan}

Investasi green sukuk telah membuka jalan bagi umat Muslim yang taat beragama untuk mendapat manfaat dari pasar modal tanpa mengorbankan keyakinan mereka. Sebuah saham green sukuk harus mendapatkan status kepatuhan syariah yang sudah terindeks pada BEI, yang paling penting adalah sumber pendapatan tidak boleh berasal dari kegiatan yang tidak diizinkan seperti meminjamkan uang dengan bunga, produk mengandung babi, alkohol, judi, spekulasi, dll. Selain itu, ekuitas harus sesuai dengan rasio keuangan berdasarkan kriteria penyaringan leverage keuangan, berkaitan dengan uang tunai yang dimiliki dan piutang usaha. Dalam praktiknya, masih terdapat beberapa kriteria yang tidak sesuai acuan seperti pembagi untuk menghitung rasio keuangan, total asset, dll. Selain perbedaan posisi keuangan, tingkat toleransi untuk kegiatan yang tidak diizinkan tidak sama antar indeks acuan. Kriteria penyaringan keuangan yang berbeda ini dapat menghasilkan portofolio yang berbeda. Selain dari komposisi portofolio yang beragam dan berbagai kinerja return, portofolio investasi berdasarkan pada uji pasar, nilai ekuitas harus dipantau lebih sering dan menyeimbangkan kembali biaya perdagangan saham.

Investasi green sukuk telah tumbuh secara eksponensial dekade terakhir. Literatur empiris terbaru menunjukkan kinerja sukuk relatif lebih baik daripada dana konvensional di Indonesia terutama saat terjadi krisis. Namun, perbandingan kinerja saham Syariah dengan konvensional tidak memiliki kekakuan karena biaya perdagangan dan manajemen yang berbeda. Untuk menetapkan kriteria penyaringan green sukuk, penggunaan indeks untuk perbandingan kinerja lebih disukai daripada penggunaan dana historis karena membuat seleksi kinerja lebih kuat karena tidak memerlukan penyesuaian untuk biaya transaksi, manajemen biaya dan/atau kemampuan manajer keuangan mengatur waktu yang tepat. Jadi, manfaat investasi tidak hanya dirasakan oleh investor tetapi juga lingkungan sekitar.

Penelitian ini memberikan perbandingan karakteristik pengembalian risiko JII\&SRIKEHATI berdasarkan pada berbagai kriteria pemilihan syariah berdasarkan acuan 
mendukung keberlangsungan lingkungan dengan memanfaatkan data cross sectional satu tahun terakhir untuk JII\&SRI dibangun oleh dua indeks utama: JII dan SRI KEHATI. Masing-masing penyedia indeks menggunakan kriteria penyaringan syariah yang berbeda terutama untuk faktor keuangan untuk memasukkan saham dalam indeks. JII menggunakan nilai buku total aset untuk menghitung rasio keuangan (accrual basis) dan pemilihan kapitalisasi tertinggi dari saham syariah. Sementara SRI KEHATI menggunakan nilai ekuitas pasar untuk perhitungan rasio keuangan (metode cash basis). Penelitian ini menyelidiki apakah kriteria penyaringan syariah berwawasan lingkungan menghasilkan risiko-abnormal return dengan menggunakan data saham untuk periode 20 Juni 2018 hingga 11 Juni 2019.

Temuan empiris diperoleh dengan menggunakan beberapa perbedaan model pengukuran kinerja dalam satu persamaan serta dalam kerangka multi-equation. Indeks lingkungan dicocokkan sebagai patokan untuk JII dan ternyata belum semua saham syariah mendukung keberlangsungan lingkunan. Penggunaan kerangka kerja multi-equation adalah salah satu kontribusi utama dalam tulisan ini. Kerangka kerja multi- equation menggunakan model SUR diterapkan pada kelompok green sukuk berdasarkan kriteria penyaringan yang berbeda digunakan oleh masing-masing penyedia indeks. Kerangka kerja multi-equation menghasilkan estimasi koefisien dan pengujian koefisien yang lebih baik. Hasil empiris dengan kerangka kerja ini menunjukkan bahwa green sukuk, rata-rata menghasilkan abnormal return mengikuti kriteria penyaringan Syariah berwawasan lingkungan kuantitatif yang diadopsi oleh SRI KEHATI. Namun, indeks syariah tersebut mencerminkan abnormal return yang menurun dan butuh penyeimbangan keuangan kembali di mana saham berkinerja rendah diganti sebelum terjadi penurunan ekonomi. Temuan ini sejalan dengan penelitian, Ashraf (2016) bahwa abnormal return yang menurun harus segera diganti sebelum memengaruhi kondisi ekonomi.

Temuan penelitian ini menarik bagi pembuat kebijakan, praktisi dan masyarakat umum yang akan melakukan investasi. Investor dalam saham syariah tidak mengganggu keimanan karena patuh terhadap perintah agama dapat mengharapkan return dan risiko disesuaikan mirip dengan indeks acuan konvensional. Temuan studi ini relevan dalam pengukuran kinerja manajer keuangan. Penggunaan acuan green sukuk yang sesuai untuk pengukuran kinerja JII\&SRI berdasarkan kriteria penyaringan yang diadopsi oleh indeks ICMA menyediakan informasi lebih relevan tentang keterampilan manajemen manajer keuangan. Selanjutnya perlu dilakukan perampingan standar penyaringan green sukuk untuk menghindari kebingungan di antara investasi publik. Baik pembuat kebijakan dan pengelola dana dapat memperoleh manfaat dengan berpegang pada kriteria terpadu tanpa kehilangan signifikansi untuk mengembalikan kinerja. Hal ini menarik dan akan membantu lebih banyak investor yang menganut keyakinan yang ingin berinvestasi di pasar modal. Para pengelola dana konvensional juga dapat memperoleh manfaat dengan memegang portofolio investasi yang dikelola mematuhi prinsip-prinsip Syariah.

Penelitian ini menyelidiki hubungan antara kriteria penyaringan dan kinerja green sukuk tanpa mempertimbangkan transaksi biaya dan/atau likuiditas. Namun, untuk portofolio pasif yang sering membutuhkan penyeimbangan kembali dapat sangat berbeda dari portofolio yang lebih pasif karena biaya transaksi dan risiko likuiditas. Penelitian ini dapat mendukung penelitian lebih lanjut dan mengatasi masalah dalam praktik investasi. 


\section{DAFTAR PUSTAKA}

Ashraf, Dawood. 2016. Does Shari'ah Screening Cause Abnormal Returns?: Empirical Evidence from Islamic Equity Indices. J Bus Ethics (2016) 134:209-228. Springer Science+Business Media Dordrecht 2014.

Azman, Syed Marwan Mujahid bin Syed dan Engku Rabiah Adawiah Engku Ali. 2016. Potential Role of Social Impact Bond and Socially Responsible Investment Sukuk as Financial Tools that Can Help Address Issues of Poverty and Socio-Economic Insecurity. Intellectual Discourse, Special Issue (2016) 343-364.

Fatimatuzzahra, Vita dan Leo Herlambang. 2014. Reaksi Pasar Atas Penerbitan Sukûk (Studi Pada Emiten Saham Penerbit Sukûk Periode 2008-2012). JESTT Vol. 1 No. 5 Mei (2014).

Hakim, S., \& Rashidian, M. 2004. Risk \& return of Islamic Stock Market Indexes. In Forum Annual Conference in Sharjah, UAE. (Online) http://www.iefpedia.com, diakses pada 11 Juni 2019,.

Hanafi, Mamduh M. 2016. Manajemen Keuangan Edisi 2. Yogyakarta: BPFE

Hidayat, Taufik. 2011. Buku Pintar Investasi Syariah. Jakarta: mediakita.

Huberman, G., \& Kandel, S. (1987). Mean-variance Spanning. Journal of Finance, 42, 873888.

Kwoun, Young Man, Mohamad Hamzi Abdul Azziz, dan Kyung Nam Kim. 2018. Penelitian tentang Keuangan Hijau Islam: Memahami Sukuk Hijau dengan Studi Kasus Proyek LSS Energi Tadau. New \& Renewable Energy 2018. 6 Vol. 14, No. 2. ISSN 1738-3935.

Marwan, Syed dan Prof. Dr. Engku Rabiah Adawiah Engku Ali. 2016. The Potential of Innovative Financial Tools: Social Impact Bond (SIB) and Sustainable and Responsible Investment (SRI) sukuk, Towards The Sustainable Growth of The Islamic Finance Industry. EJIF - European Journal of Islamic Finance. No 4, March (2016). ISSN 2421-2172.

Morea, Donato dan Luigi Antonio Poggi. 2017. An Innovative Model for the Sustainability of Investments in the Wind Energy Sector: The Use of Green Sukuk in an Italian Case Study. International Journal of Energy Economics and Policy, 2017, 7(2), 53-60. ISSN: 2146-4553. JEL Classifications: Q420, L940, P480.

Naifar, Nader. 2018. Exploring the Dynamic Links between GCC Sukuk and Commodity Market Volatility. International Journal of Financial Studies, 2018, 6, 72.

Otoritas Jasa Keuangan (OJK). 2019. Peraturan Nomor II.K.1 tentang Kriteria dan Penerbitan Daftar Efek Syariah. (Online) www.ojk.go.id, diakses pada 15 Juni 2019.

Otoritas Jasa Keuangan (OJK). 2019. POJK No.60/POJK.04/2017 Penerbitan dan Persyaratan Efek Bersifat Utang Berwawasan Lingkungan. (Online) www.ojk.go.id, diakses pada 15 Juni 2019. 
Rahim, Siti Rohaya Mat dan Zam Zuriyati Mohamad. 2018. Green Sukuk for Financing Renewable Energy Projects. TUJISE (Turkish Journal of Islamic Economics), 5 (2), 2018, 129-144. Research Center for Islamic Economics.

Schroder, M. 2007. Is there a difference? The Performance Characteristics of SRI Equity Indices. Journal of Business Finance \& Accounting, 34(1-2), 331-348.

SIARAN PERS Kuala Lumpur, 8 November 2017. Regulator Pasar Modal Luncurkan Standar Green Bond ASEAN untuk Pacu Investasi Berkesinambungan.

United Nations Environment Programme (UNEP). 2019. Towards a Sustainable Financial System in Indonesia: The UNEP Inquiry Into the Design of a Sustainable Financial System. (Online) https://www.ojk.go.id, diakses pada 28 Maret 2019.

Zellner, A. (1962). An Efficient Method of Estimating Seemingly Unrelated Regression and Tests for Aggregation Bias. Journal of the American Statistical Association, 57(298), $348-368$.

https://finance.yahoo.com/, diakses pada 11 Juni 2019

https://www.idx.co.id/, diakses pada 11 Juni 2019

https://www.ojk.go.id, diakses pada 28 Maret 2019

https://market.bisnis.com/read/20181010/92/847518/green-sukuk-instrumen-investasipembangunan-berkelanjutan, diakses pada 29 Maret 2019

https://www.republika.co.id/berita/ekonomi/keuangan/18/10/09/pgbpni370-green-sukuktetap-jadi-andalan-di-2019, diakses pada 29 Maret 2019.

https://www.undp.org/content/undp/en/home/blog/2018/Indonesias-green-sukuk.html, diakses pada 29 Maret 2019.

https://www.cnnindonesia.com/ekonomi/20190214155316-532-369338/pemerintahterbitkan-green-sukuk-global-us-2-miliar, diakses pada 29 Maret 2019.

Green Financing, Sukuk.pdf "Green Financing, Sukuk Negara dan Pembangunan Berkelanjutan.” (Eri Hariyanto, Ahli Madya Pusdiklat Keuangan Umum BPPK)

roadmap-keuangan-berkelanjutan-sarana-berinovasi-ljk.pdf

$\underline{\text { Siaran Pers 112.pdf }}$ 


\section{LAMPIRAN}

Uji Wald

Wald Test:

Pool: UJI_WALD

\begin{tabular}{lccc}
\hline \hline Test Statistic & Value & df & Probability \\
\hline \hline F-statistic & 701.9495 & $(2,2562)$ & 0.0000 \\
Chi-square & 1403.899 & 2 & 0.0000 \\
\hline \hline
\end{tabular}

Null Hypothesis: $C(1)=0, C(2)=0$

Null Hypothesis Summary:

\begin{tabular}{lcc}
\hline \hline Normalized Restriction $(=0)$ & Value & Std. Err. \\
\hline \hline $\mathrm{C}(1)$ & 0.000281 & 0.000333 \\
$\mathrm{C}(2)$ & 1.353892 & 0.036198 \\
\hline \hline
\end{tabular}

Restrictions are linear in coefficients.

\section{Uji LM}

Lagrange multiplier (LM) test for panel data

Date: 06/19/19 Time: 15:06

Sample: 6/20/2018 6/11/2019

Total panel observations: 2574

Probability in ()

\begin{tabular}{lcll}
\hline \hline $\begin{array}{l}\text { Null (no rand. effect) } \\
\text { Alternative }\end{array}$ & $\begin{array}{c}\text { Cross-section } \\
\text { One-sided }\end{array}$ & $\begin{array}{c}\text { Period } \\
\text { One-sided }\end{array}$ & Both \\
\hline \hline Honda & -1.629942 & 32.34970 & 21.72215 \\
& $(0.9484)$ & $(0.0000)$ & $(0.0000)$ \\
King-Wu & -1.629942 & 32.34970 & 4.966415 \\
& $(0.9484)$ & $(0.0000)$ & $(0.0000)$ \\
GHM & -- & -- & 1046.503 \\
& -- & -- & $(0.0000)$ \\
\hline \hline
\end{tabular}

